\title{
The Lichtenberger Prophecy and Melanchthon's Horoscope for Luther
}

\section{Jürgen G.H. Hoppmann}

The Reformation coincided with a boom in the publication of astrological almanacs and astrology became a potent means of propagandising for differing political positions. One of the most notable Reformation astrologers was Philipp Melanchthon (1497-1560), professor of Greek at Wittenberg from 1518, where he became one of Martin Luther's closest friends and collaborators. ${ }^{1}$ In 1521 he briefly found himself leader of the Reformation when Luther was confined in the Wartburg. His interest in astrology and his position at the centre of the Reformation raises important questions concerning the possible use of astrological forecasts of the Reformation's future course. Martin Luther's birth chart was to become a focus of debate amongst astrologers who wished to establish whether he was a new messiah or the AntiChrist.

\section{The Lichtenberger Prophecy}

The astrological debates concerning Luther's destiny took place in the context of an earlier prophecy which dated back to 1415, when Jan Hus, the Bohemian religious reformer, was burned at the stake. According to this prophecy a new reformer, perhaps even the Messiah, would be born a hundred years later, and when it was included in Johannes Lichtenberger's predictions, published in Heidelberg in 1488, it became part of the currency of late fifteenth century prognostication. ${ }^{2}$

Luther himself took this prophecy personally when he wrote that 'St. Johann Hus has prophesied about me, when in prison in Bohemia he wrote: they are roasting a goose [Hus = goose in Bohemian] now; but in a hundred years they are going to hear a swan sing for which they shall suffer. That it shall be, as God wants'. ${ }^{3}$ Naturally his enemies placed a different interpretation on the prophecy, for in their view the leader of the Reformation was in league with the Devil.

The extent to which astrological forecasts may have influenced the general apocalyptic mood of the Reformation is still to be satisfactorily dealt with. When, for example, Luther nailed his 95 theses to the door of Jürgen G.H.Hoppman The Lichtenberger Prophecy and Melanchthon's Horoscope for Luther, Culture and Cosmos, Vol. 1 no 2, Autumn/Winter 1997, pp. 49-59. 
the court church at Wittenberg in October 1517, issuing his public challenge to Rome, he cannot have been unaware of the forecasts that the Jupiter-Saturn conjunction of 1524 warned of a second great deluge. ${ }^{4}$

It was actually in 1524 that Luther himself arranged for a new publication of Lichtenberger's predictions, which had placed the birth of the Messiah in 1484 on the basis of that year's Jupiter-Saturn conjunction, adding a new preface by himself. Luther, who was born in $1483 / 4$, clearly believed that the forecast referred to him, but used it as a starting point for his own personal statements on the correct theological attitude to astrology. ${ }^{5}$

Was sagen wir denn zum Lichtenberger und des gleichen? Das sage ich. Erstlich/ Den grund seiner Sternkunst halt ich fur recht/ aber die kunst ungewis/ das ist/ Die zeichen am hymel und auff erden feylen gewißlich nicht/ Es sind Gotts und der Engel werck/ warnen und kunst darauff zu machen ist nichts/ und ynn die sterne solchs zu fassen. Zum andern/ es mag dennoch wol daneben sein/ das yhn Gott odder sein Engel bewegt habe/ viel stucke/ wilche gleich zutreffen/ zu schreiben/ wie wol yhn das Gott sehen ließe/ das die Kunst yngewisse sey/ hat er yhn lassen f eylen etliche mal.

Und ist das summa summarum davon/ Christen sollen nichts nach selcher weissagung fragen/ denn sie haben sich Gott ergeben/ durffen solchs drewens und warnens nicht. Weil aber der Lichtenberger die zeichen des hymels anzeucht/ so sollen sich die gottlosen herren und lenden fur allen solchen weissagungen furchten.

What are we then saying about Lichtenberger and his like? This is what I say. Firstly I consider the rational basis of his celestial art as right, while the art itself is uncertain. That is, the signs in heaven and on earth do not fail. They are the work of God and the angels, sent to warn us, and it is nothing to make an art out of it and to attribute such connections to the stars. Secondly next to this it nevertheless might be that God or his angels have moved him [Lichtenberger] to make many forecasts which have come true, but to let him understand that the art is uncertain God has let him fail many times. 


\begin{abstract}
And this is our conclusion: Christians should not ask for such a prophecy because they have devoted themselves to God and therefore don't need such readings and predictions.But because Lichtenberger indicates the signs of the sky, godless people become afraid of all such prophecies.'
\end{abstract}

\title{
Luther's Horoscope
}

The central question for any contemporary astrologer keen to know whether Luther was the Messiah or the anti-Christ, was his date, place and time of birth. Melanchthon studied astrology at Thubingen under Johannes Stoeffler from 1512-1518 and from then on he considered knowledge of astrology to be a standard part of humanism. Melanchthon's correspondence indicates that in 1530 his interest was increasingly focused on astrology. ${ }^{6}$ Until now he had been occupied defending the Reformation in texts such as the Augsburg Confession. Now he was able to devote himself to the interests he had brought from Swabia to Saxony. It was also in 1530 that Lucus Gauricus, the wellknown Italian astrologer, is said to have come to Berlin. ${ }^{7}$ Gauricus, an enthusiastic supporter of the Roman Catholic Church, was now under the jurisdiction of Joachim I, the Elector of Brandenburg, who had himself resisted pressure for a reformation of the Church in his territory, and also employed his own astrologer, Johann Carion.

During Gauricus' visit to Joachim I he began a correspondence with Melanchthon, who was based in Wittenberg, the capital of Lutheran Saxony. ${ }^{8}$ Their particular interest was the time and date of Luther's birth. Melanchthon was Luther's closest friend and companion, and at the same time a passionate astrologer, and even though Gauricus was a Catholic, it was therefore natural for him to consult Gauricus in his rectification of Luther's 'Constallatio'. The matter was of great political importance: was the founder of the Reformation born in the year 1484, under a powerful concentration of planets in the bad sign of Scorpio, and therefore the Antichrist? Or perhaps in 1483 with more favourable planetary alignments, perhaps indicating that he was destined for the vacant post as 'the New Pope in the New Rome, Wittenberg'.

However, not only could Luther's mother not remember the time of her son's birth, even though in one account she reported that he was born at midnight, but Luther himself had made different statements about his chart, and even his year of birth was open to dispute. ${ }^{9}$ Luther of course, 
was well aware of the propaganda uses to which his horoscope would have been put.

\section{Forgery and Truth}

As an authority in the field Melanchthon had a free hand to rectify Luther's horoscope as he saw fit, using the known events of his life to determine a likely birth time. However, he offered to consult with his colleagues. In 1532 he wrote to another astrologer, Schonerum, almost certainly Johannes Schoener, who was based in Nuremberg that the birth time of 9 pm (on October 22, 1484) was rectified by Carion. In this chart the stellium of Sun, Mercury, Venus, Jupiter and Saturn in Scorpio fell in the 5th house. Did the astrologer see this as a beneficial indication, and was this chart rectified for political reasons rather than astrological? Melanchthon's doubts continued and in 1539 he wrote to his friend Osiander, 'We are in doubt about Luther's birth time. The day is certain, almost the hour, midnight, as I myself have heard his mother saying. I think the year was 1484. But we drew several charts. Gauricus accepted the horoscope of 1484'. ${ }^{11}$ Melanchthon's student Erasmus Reinhold (1511-1553), used this chart many years later but with the comment 'Coniecturalis', indicating the speculative character of the calculation. ${ }^{12}$ By accepting 1484 as Luther's year of birth Gauricus was setting out an unfavourable horoscope for Luther, ${ }^{13}$ a precedent followed later on by Cardan in Italy.

Gauricus' preferred birth time for Luther was 1:10 am, while Philo Pfeil argued for 3:22 am, both for October 22nd 1484. ${ }^{14}$ In Gauricus' version Mars falls in the 1st house - a more aggressive component and the concentration of planets in Scorpio falls in the 9th, the house of religion. His conclusion was that Luther was more likely sent by Satan than God:

Martin had been a monk for many years and learned to live the monastic life. He married an abbess of tall stature from Wittenberg who gave birth to two children. The meeting of five planets in the sign of Scorpio in the ninth house, which the Arabs assign to religion, is strange and sufficiently frightening. It makes him a sinner, a heretic, the worst enemy of Christian religion and it makes him profane. When the Ascendant by direction was conjunct Mars the Infidel perished. His depraved soul went to hell 
where it is continually tortured with glowing whips by Allectus, Tesiphon and Megera. ${ }^{15}$

Gauricus' conclusion is substantiated by astrological arguments, but we have to take into account the possibility that his work was influenced by his own position in the service of Catholic lords. It is possible that Gauricus was making a public statement of opposition to Luther in order to safeguard his own position. Was there, perhaps, some understanding between astrologers that their public words did not always reflect their private positions?

The Italian astrologer Jerome Cardan used the same data as Gauricus, but criticised his interpretation, which in his view lacked the appropriate Counter-Reformational fervour. He also changed the year of birth to 1483, which was increasingly used as an alternative to $1484,{ }^{16}$ a precedent followed by Melanchthon himself. Cardan, meanwhile, was even more disapproving of Luther than Gauricus, perhaps because, like Gauricus, he wished to safeguard his position by demonstrating his loyalty to Rome. ${ }^{17}$ Melanchthon subsequently repeated his belief that Luther was born in 1483 in the deanship-book of Wittenberg University as well as in his eulogy for Luther. ${ }^{18}$

Thirty years after Luther's death, Johann Garcaeus published a collection of natal horoscopes in which Luther's birth data were given as $11.20 \mathrm{pm}$ on November 10th 1483, the date which is now accepted as Luther's official birthday. Like Gauricus, Garcaeus placed Luther's natal Moon in the ninth house, representing religious and ecclesiastical affairs. Aby Warburg reckons that 'the empathic natural vitality' of Gauricus' original Italian chart continued to have an effect on Garcaeus. ${ }^{19} \mathrm{He}$ also mentioned that in 1617 the whole subject of Luther's disputed birth time was 'scientifically solved by the Protestants..."

The question of Luther's birth date was revived when a note by Luther was found in the archive of Melanchthon's house at Bretten, consisting of an outline of his life. The so-called page of Bretten implies that the reformer was born towards midnight on November 11th 1484. Melanchthon, then, was right to question Luther's birth data. The saga of the conflicting birth charts published for Luther raises two vital questions in the history of astrology. First there is the problem of conflicting astrological techniques and interpretations. Second, and more important from an historical perspective, is the problem of how far, at a time of intense political and religious conflict, astrologers felt compelled to 
shape their public pronouncements to satisfy political and theological pressures.

\section{References}

1. For a recent discussion of Melanchthon's use of astrology and arguments in its defence, see Stefano Caroti, 'Melanchthon's Astrology' in Paola Zambelli (ed.), Astrologi hallucinati - Stars in the End of the World in Luther's Time, Berlin, 1986. See also Dieter Muller Wolf, 'Jahucke: Magister Philippus und die Astrologie' in Jürgen Hoppmann, Melanchthon's Astrologie, Wittenberg, 1997, and Jürgen Hoppman, Astrologie dei Reformationszeit, Berlin 1997.

2. Lichtenberger, Prognosticatio in Latino, Heidelberg, Heinrich Knoblochtzer, 1488. See Dietrich Kurze, Johannes Lichtenberger - Eine Studie zur Geschichte der Prophetie und Astrologie, Lubeck 1960.

3. Joestel, Volkmar: Legenden um Martin Luther, Berlin 1992, p 28, footnote. See also D.Martin, Luthers Werke. Kvitsche Gesamtausgabe, Die Deutsche Bibel, Bd, 1-63ff, Weimar, 1883-1987 ff WABi 11,2,5,881 16-70.

4. These forecasts are amply dealt with by Lynn Thorndike, History of Magic and Experimental Science, Vol. V, chap X1, p 378-405, New York 1965. They can be traced to an almanac issued at Ulm in 1499 and achieved a wide currency in the following years. See also Caroti, 'Melanchthon's Astrology' (note 1).

5. Warburg, Aby, Heidnisch-antike Weissagungen in Wort und Bild zu Luthers Zeiten, Hamburg 1919 (Ancient pagan prophecies in words and pictures in the times of Luther), p 85.

6. Melanchthon, Philipp, Innate doctrine physic, Wittenberg 1550; Wittenberg 1559 by Peter Seitz; Oratio de dignitate astrologiae, Wittenberg 1537; Translation of Claudius Ptolemy, Tetrabiblos, with preface, CR XVIII; Tetrabiblos: after the rare edition, obtained by Philipp Melanchton, from 1553, translated into German by Erich Winkel, reprint 1923 with preface by Thomas Schaefer, Moessingen 1995; further sources: Corpus Reformatoricum (CR).

7. Warburg, 1919, p 22. Warburg's theory that Gauricus went to Berlin is doubtful. The charts from Gauricus are in Berlin but they could have gone there by post. Gauricus' biographer Percopo doesn't mention any journey to Berlin in his work, according to Rudiger Plantiko; Percopo, Erasmo, Luca Gaurico, Atti della reale accademia die archeologia, lettre de belle arti, XVII, Napoli 1896.

Culture and Cosmos 
8. See Heinz Scheible (ed), Melanchthons Briefwechsez (Regesten), Stuttgart. See also Warburg, 1919, p 12-20.

9. F.S.Keil cited in Knappich, Geschichte der Astrologie, Ffm 1967, S. p 202 quotes Luther as saying 'my mother said between 11 and 12 pm'. For Luther's Mother see Staats, Reinhold, 'Nocheinma: Luthers Gebunsjahr 1484' in Hoppmann, Melanchthon's Astrologie (note 1). For Luther's comments see also Kroker E., 'Nativitaten und Konstellationen aus der Reformationszeit', in Schrifen des Vereins fur die Geschichte Leipzig, Band 6, Leipzig 1900.

10. 'Philipus ad Schonerum', Bayerische Staatsbibliothek (Bavarian National Library), Cod. Monac, lat. 27003. Also, see Warburg, op cit.

11. CR (Corpus Reformaticorum) IV, Bretschneider, C.G., (ed.), Schleswig, 1852, S. 1053.

12. Erasmus Reinhold, Horoskopbuch, Stadtbibliothek Leipzig, Cod DCCCCXXXV, B1. 158.

13. Gauricus, Lucas, Tractatus Astrologicus, fol. 69v, Venice 1552

14. Plantiko, Rudiger, Lucas Gauricus - Ein Astrologe der Renaissance, Zurich 1993; see also Rudiger, 'Die Horoskope Luthers und Melanchthons in der Deutung durch Lucas Gauricus', in Hoppman (ed.), Melanchthons Astrologie (note 1).

15. Gauricus, Lucas, Tractatus Astrologicus, fol. 69v, See also Warburg, page 16 , note 23 .

16. Hieronymi Cardani, Liber de Iugiciis Genitarum, libelli due, geniturae LXVIII, Nurnberg, 1543.

17. Eberl, Nikolaus, Cardanus Encomium Neronis, dissertation, Frankfurt, 1994.

18. CR, VI, P 155, NO 3478

19. Warburg, 1919, op. cit., p 20.

20. Warburg, op. cit., p 20, n 41.

21. Staats, Reinhard: Luthers Geburtstjahr 1484 und das Geburtsjahr der evangelischen Kirche 1519 (Luther's birthday 1484 and the year of birth of the Protestant Church 1519). In: Bibliothek und Wissenschaft (Library and Science), 
Vol 18, Wiesbaden 1984; Luthers Geburtsjahr 1484 (Luther's year of birth 1484). In: Ebernburger Hefte (Ebernburg journals). Blaetter fuer pfaelzische Kulturgeschichte (pages of Palatine history of civilisation), Koblenz 1994. See also note 9 .

Figure 1. Luther's Horoscope according to Lucus Gauricus

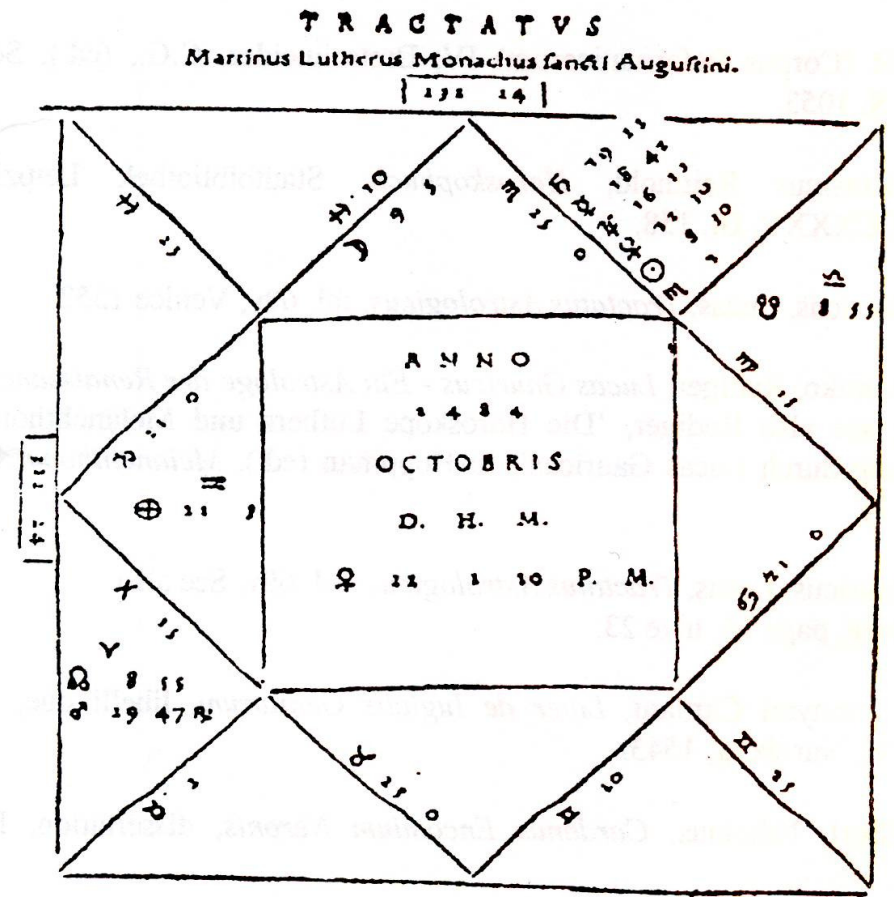

\begin{abstract}
M aretnus huir imprimis Monachus per mulsos annos, demum expolizuie habisum monialem,duxis of in vxorem A bbariffam sha Rarurg Vixriow bergenfrm \& ab illa fufeepir duos libesos. Hęc mira fatifg horrenda.s.

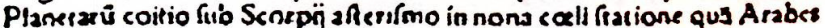
religioni depurabant, effeciu ipfum facrilegum hererkcum, Chrifiang religionis hofeem acerrimum, arop prophamum. Ex horoleopi diretione ad Mastis coirum irreligiofifsimus obït. Eius Anima Keelefirsimas ad Inferos nauigauir; ab Allefto, Ts fiphork, \& Megera Bagellin ignsis crucizea peremiser.
\end{abstract}


Figure. 2 Luther's Horoscope According to Erasmus Reinhold

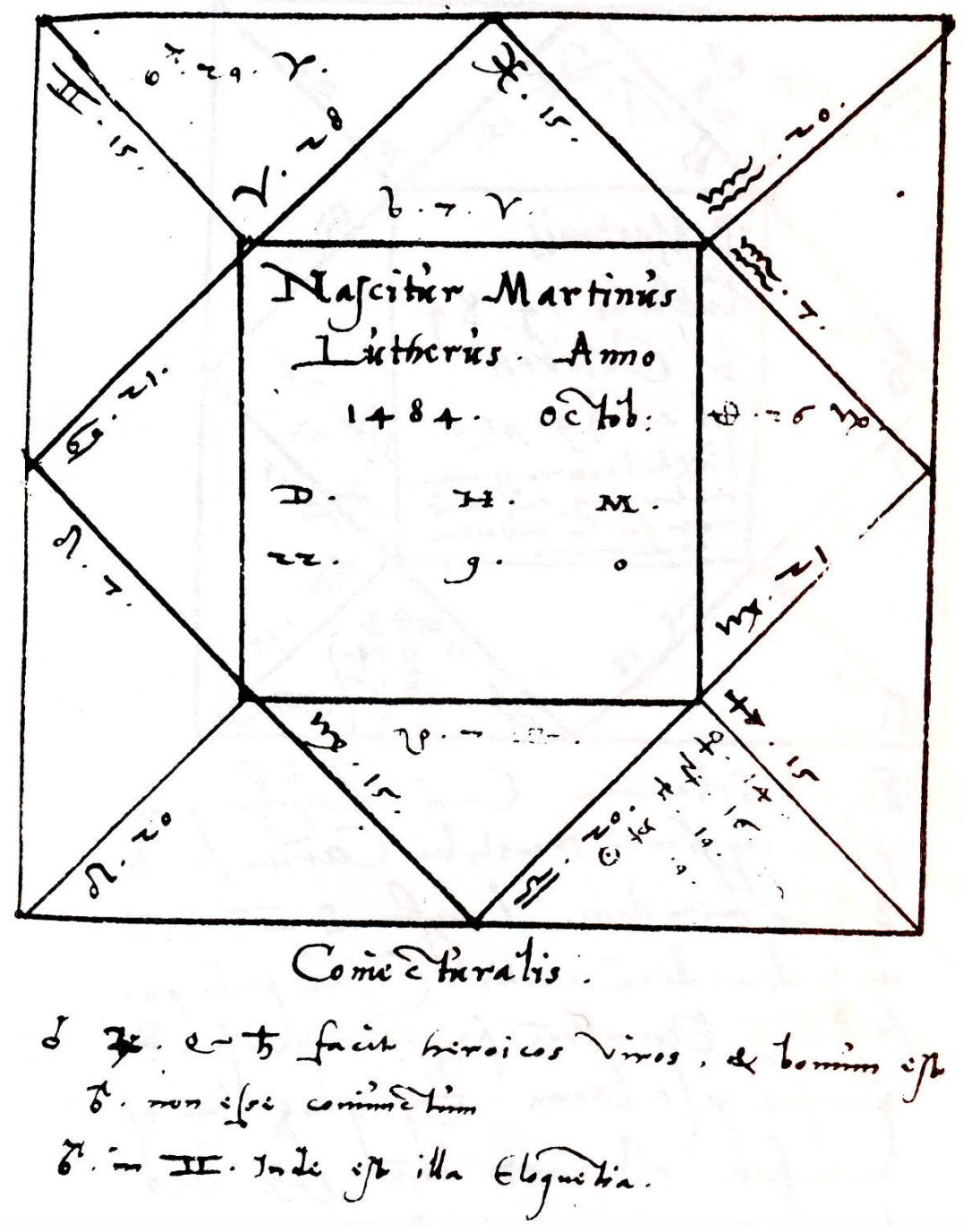


Figure 3. Luther's Horoscope According to Philip Schoener

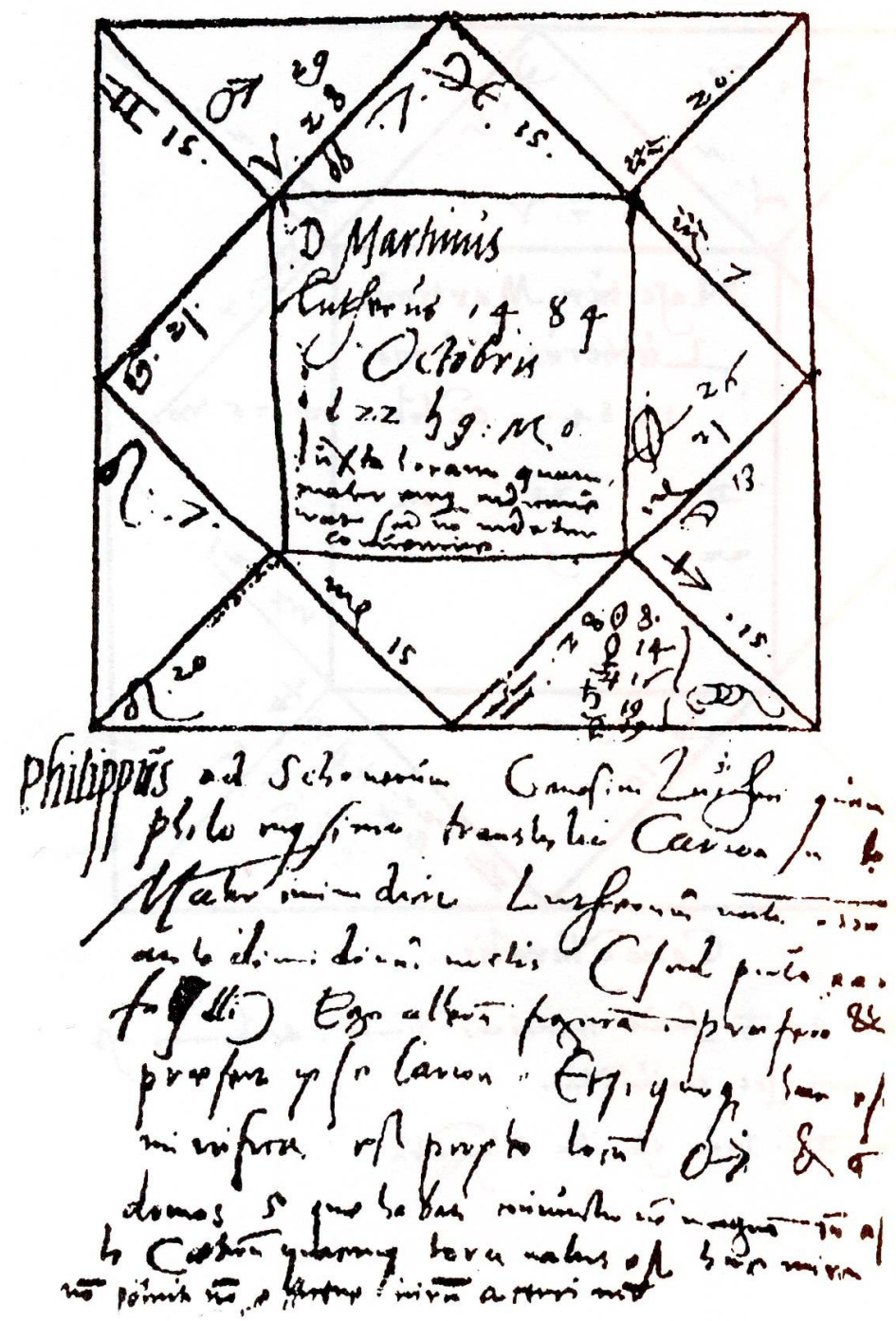

Culture and Cosmos 
Figure 4. Luther's Horoscope According to Jerome Cardan

\section{Hiek。 Cardani Lis.}

T. Anc ueram genituram Lutheri,nōeamqua fub anno 1484 publicè circumfertur, effe fcito: Nécitanto negotiominor genitura debetur, aut taligenitura minor euentus: Exiftimo aút non intelligentes huius:artis findamenta, eam corrupifle : nam nec illa robore huic aequalis eft, nec fi damnareuelis, deeft hic qd. poffis accufare. Nàm Màrs, Venus, Iúpiter'ç, fuxta uirginis fpica coëunt ad coeli imum ad unguem, ut ex horum confpiratione re. gia quardam poteftà dëcernatur; fine fceptro:funt enim erratica fub terra.Pörsớquòd ad religionem pertineat', iamr fäplus adeó dichũ eft jpropter. Spicam uirginis jut tepetere pigeat. Incredibile igitur quantumaugmenti breui tempore habuerit hoc dogma: nam Germanize. maximam partem adegit, Ahglíam totam, mul easig, alias regiónes, cum adbuc uiuat; neculla eft proulacia ab hutusfectàtoribus immunis; prater Hifpaniass. Feruet mundus huims: (chifmate; quod, quia Martem admixtũ habet \& caudam, foluitur in Seipfo, infinitafg reddit capita, ut.fi nihil aliud errorem conuińcat; multitudo ip fa opintonum oftèndère tumpoffit, cum ueritas una tantum fit; plúrimos neceffário aberrare; Porrò firmi ratem dogmatis Sol \& Sätarnus rum:lance meridionali, in loco futurze contunctionis magnex oftèndunt, cum diu trigonus ille lam domina retur. At Luna-iuxta afcendens, longitudinem deceruita : uerum cum Solí Sàturnus adiungatur,protanto rerum stu,nullam dignitatem decernit.

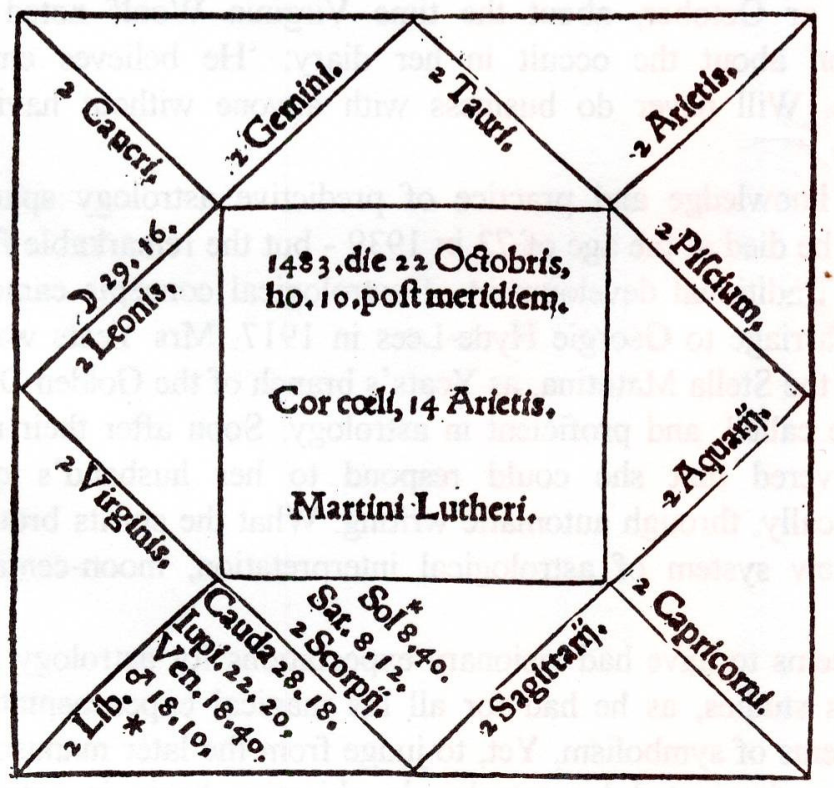

Culture and Cosmos 